\title{
KONSEP HEALING ENVIRONMENT UNTUK MENDUKUNG PROSES PENYEMBUHAN PASIEN RUMAH SAKIT
}

\author{
Ihsanudin Yusuf Nur Hafidz \\ Program Studi Arsitektur \\ Universitas Muhammadiyah Surakarta \\ e-mail: apithafidz73@gmail.com \\ Fadhilla Tri Nugrahaini \\ Program Studi Arsitektur \\ Universitas Muhammadiyah Surakarta \\ e-mail: ftn995@ums.ac.id
}

\begin{abstract}
ABSTRAK
Istilah rumah sakit menyiratkan sebuah harapan sehingga rumah sakit harus menunjang kesembuhan pasien. Bukan hanya melalui faktor medis saja, tetapi juga faktor lain yang perannya sangat penting dalam kesembuhan, yaitu faktor psikologis. Rumah sakit harus mampu mengarahkan pasien pada harapan sehat dan optimisme terhadap kesembuhan. Faktor psikologis ini dapat ditunjang dengan pendekatan lingkungan, yang tujuannya adalah membentuk persepsi melalui hubungan antara pikiran dan perilaku. Penelitian ini bertujuan untuk mengetahui respon dan tanggapan pasien terkait dengan kenyamanan suasana rumah sakit saat menjalani perawatan. Metode deskriptif kualitatif dilakukan pada penelitian ini ditunjang dengan studi literatur, wawancara dan kuesioner. Data yang dihasilkan mengarah pada manusia mempunyai keterikatan dengan alam, yang kedekatannya tidak dapat dipisahkan. Hal ini berkaitan dengan teori biophilia yang menjelaskan bahwa manusia mempunyai kecenderungan untuk berafiliasi dengan alam. Alam mempunyai sifat restoratif yang mampu memberikan energi positif terhadap psikologis manusia. Melalui peran penting ini, lingkungan harus mendapatkan porsi besar dalam penerapanya di rumah sakit. Kecenderungan sampel menunjukan bahwa lebih dari $80 \%$ atau 92 orang dari 115 orang, memilih suasana yang berhubungan dengan lingkungan alam, karena dirasa lingkungan alam dapat memberikan kenyamanan dan energi positif yang akan berpengaruh baik terhadap kesembuhan psikis pasien.
\end{abstract}

KATA KUNCl: rumah sakit, lingkungan, healing environment, proses kesembuhan.

\section{PENDAHULUAN}

Rumah sakit mempunyai pengertian rumah atau tempat merawat orang sakit, tempat yang menyediakan dan memberikan pelayanan kesehatan yang meliputi berbagai masalah kesehatan (KBBI, 2019). Dari pengertian diatas sudah seharusnya rumah sakit yang direncanakan harus memberi harapan sehat.

Rumah sakit harus mengarahkan pada harapan sehat dan rasa optimisme, sehingga peran rumah sakit tidak hanya memberikan penyembuhan secara medis saja, melainkan juga memberikan pengobatan psikis. Hal ini dapat dicapai melalui perencanaan desain rumah sakit yang sehat dan memadai. Oleh sebab itu peran rumah sakit menjadi sangat penting dalam proses penyembuhan.

Jones (dalam Kurniawati, 2007) menjelaskan bahwa faktor lingkunganlah yang berperan besar dalam proses penyembuhan manusia, yaitu sebesar 40 $\%$, sedangkan medis hanya $10 \%$, faktor genetis $20 \%$, dan faktor lain $30 \%$. Berkaitan dengan peran besar faktor lingkungan terhadap proses penyembuhan itulah, maka sudah seharusnya lingkungan mendapat porsi besar dalam desain rumah sakit.

Berdasarkan pertimbangan tersebut akan lebih baik jika rumah sakit menerapkan konsep lingkungan sebagai proses penyembuhan psikis pasien. Selain itu dalam merencanakan desain, faktor lingkungan dapat diarahkan pada konsep Healing Environment.

Konsep Healing Environment berkembang dari sebuah riset yang dilakukan oleh Robert Ulrich, direktur Center for Health System \& Design, Texas A\&M University, Amerika Serikat. Riset tersebut menekankan pada kebutuhan pengguna. Pengguna yang dimaksud adalah pasien pada fasilitas pelayanan kesehatan. Riset tersebut membuktikan bahwa lingkungan tempat sebuah fasilitas pelayanan kesehatan berada berpengaruh besar pada kualitas proses penyembuhan yang berlangsung di dalamnya.

Selain faktor lingkungan, ada faktor-faktor lain yang mempengaruhi proses kesembuhan, diantaranya adalah:

1. Faktor medis

Penanganan medis dibutuhkan seseorang untuk mencapai penanganan pertama untuk meredakan 
penyakit, yaitu dengan pengobatan yang dilakukan sesuai dengan ilmu kesehatan seperti meminum obat, terapi fisik, dan lain-lain.

2. Faktor genetik bawaan.

Faktor genetik yang dimaksudkan bukanlah faktor genetik keturunan, melainkan faktor genetik bawaan yang dimiliki oleh masing-masing individu. Analoginya seorang yang merokok tidak semua mengalami kanker paru-paru, ada faktor lain dan salah satunya faktor genetik. Faktor genetik bawaan yang berpengaruh terhadap terjadinya kanker pada seorang pasien.

\section{Faktor psikologis manusia}

Faktor psikologis merupakan faktor yang penting dan memiliki peranan dalam proses penyembuhan penyakit. Faktor psikologis merupakan faktor dari dalam yang prinsip penyembuhannya memberikan dorongan positif melalui psikis pasien. Di antara faktor psikologis dalam penyembuhan penyakit adalah :

a. Menghindari kecemasan

b. Menghilangkan depresi

c. Kehidupan sosial

d. Dukungan keluarga

e. Kepercayaan pasien pada diri sendiri

f. Mempercayai penangan medis

g. Kehidupan relegius

h. Berpikiran positif

i. Pola hidup

j. Kondisi psikologis

Healing Environment adalah konsep yang di dalamnya memuat tiga aspek penting terhadap proses kesembuhan pasien, yaitu:

1. Aspek Healing Environment adalah lingkungan alam. Lingkungan alam dinilai mampu memberikan energi positif terhadap psikologi manusia, yang memberikan kenyamanan dan rileksasi terhadap suasana pikiran manusia.

2. Aspek psikologi. Konsep Healing Environment dalam penerapannya mampu memberikan sugesti positif terhadap kesehatan psikis pasien. Sugesi positif tersebut mampu membangkitkan rasa optimisme dan harapan sehat bagi pasien.

3. Aspek panca indra manusia. Konsep Healing Environment harus mampu memberikan rangsangan terhadap kelima panca indera manusia melalui penglihatan, aroma, suarasuara, dan tekstur, yang diwujudkan dalam elemen-elemen alam.

Prinsip konsep Healing Environment, tidak hanya diterapkan pada desain bagian luar (tata ruang luar) tetapi juga bagian dalam (tata ruang dalam) bangunan. Inti dari konsep ini adalah membangun suasana melalui penyesuaian semua elemen desain untuk dapat memberikan rangsangan positif bagi kelima panca indera manusia. Prinsip-prinsip penerapan konsep tersebut sebagai berikut (Subekti, dalam Kurniawati, 2007) :

a. Desainnya harus mampu mendukung proses pemulihan baik fisik maupun psikis seseorang.

b. Akses ke alam.

c. Adanya kegiatan-kegiatan outdoor yang berhubungan langsung dengan alam.

d. Desainnya diarahkan pada penciptaan kualitas ruang agar suasana terasa aman, nyaman, tidak menimbulkan stress.

Tujuan dari penelitian ini adalah untuk mengetahui respon dan tanggapan pasien terkait dengan kenyamanan suasana rumah sakit saat menjalani perawatan. Selain itu mengetahui faktorfaktor yang dapat mempengaruhi proses kesembuhan pasien saat menjalani perawatan di rumah sakit, dan untuk mengetahui tentang peran konsep Healing Environment pada rumah sakit terhadap proses kesembuhan pasien.

\section{METODE PENELITIAN}

Metode penelitian yang digunakan penulis adalah metode deskriptif kualitatif. Metode kualitatif merupakan metode untuk memperoleh data dengan menganalisis langsung di lapangan. Penulis akan memperoleh data berdasarkan hasil kuesioner, wawancara, dan analisis terhadap objek yang diteliti. Metode ini memungkinkan penulis mendapatkan data yang relefan berdasarkan pernyataan dari narasumber yang pernah merasakan pengalaman terkait dengan topik pembahasan. Adapun tahapan pengumpulan data sebagai berikut :

\section{Tahap pertama}

Tahapan pertama adalah studi pustaka, yaitu mencari data-data tentang kecenderungan sifat manusia, hubungan mausia dengan alam, faktorfaktor yang menyebabkan penurunan kesehatan manusia, faktor penyebab stres, manfaat alam terhadap psikologis manusia, faktor-faktor pendorong proses kesembuhan, yang kemudian akan dijadikan sebagai dasar pencarian data.

2. Tahap kedua

Tahapan kedua adalah memberikan kuesioner dan wawancara. Tahapan ini dilakukan untuk mengetahui respon dan kecenderungan pasien terhadap suasana rumah sakit, yaitu melalui beberapa pernyataan dan gambar-gambar berkenaan dengan psikologis dan lingkungan. Respon yang dipaparkan oleh masyarakat dapat diambil sebagai data untuk dianalisis.

Sistem penilaian kuesioner diambil dari jumlah pilihan terbanyak dari setiap kasus yang disuguhkan. Dengan data jumlah pilihan terbanyak itulah akan dijadikan sebagai sumber data utama penelitian. 
Responden berjumlah 115 dan data yang diperoleh dari responden merupakan data yang bisa dibuktikan kebenarannya. Responden mewakili semua kalangan masyarakat, berdasarkan jenis kelamin, umur, status sosial dan pekerjaan.

3. Tahap ketiga

Tahapan ketiga adalah membuat kesimpulan dari hasil kuesioner, kemudian melakukan korelasi antara literatur dengan data kuesioner dan wawancara yang diperoleh. Kesimpulan merupakan akhir penelitian.

Teknis analisis data akan melibatkan kesimpulan dari beberapa literatur tentang psikologis manusia, hubungan manusia dengan alam, psikologi kesehatan dan psikologi klinis. Kesimpulan dari beberapa literature dikorelasikan dengan hasil data kuesioner dan wawancara sesuai kondisi yang nyata di lapangan. Dengan data-data tersebut akan ditarik kesimpulan tentang hubungan dari masing-masing data terhadap Konsep Healing Environment dan peran Konsep Healing Environment yang dapat mempengaruhi proses kesembuhan terhadap pasien.

\section{HASIL ANALISIS DAN PEMBAHASAN}

\section{Data Responden}

Jumlah responden 115 orang, 61 (53\%) orang pernah dirawat di RS, dan 54 (47\%) orang belum pernah dirawat di RS.

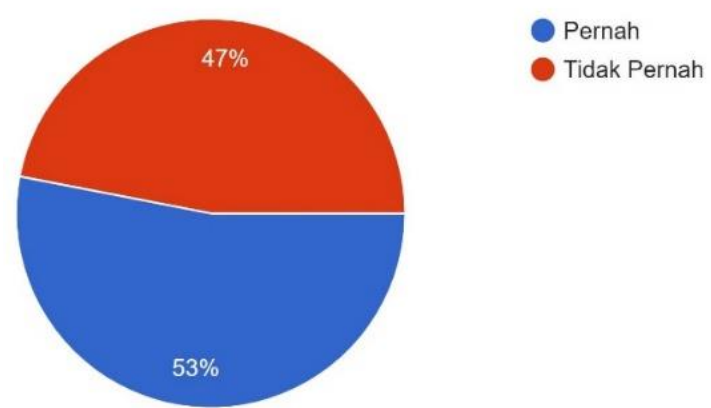

Gambar 1. Profil responden pernah dirawat/tidak di RS. (Sumber : Analisis Penulis, 2019)

Tabel 1 Data Responden

\begin{tabular}{|c|c|}
\hline $\begin{array}{l}\text { Jenis } \\
\text { Kelamin }\end{array}$ & $\begin{array}{l}49 \text { orang }(42.6 \%) \text { laki-laki dan } 66 \text { orang } \\
(57.4 \%) \text { perempuan. }\end{array}$ \\
\hline Umur & $\begin{array}{l}\text { - } 17-24 \text { tahun sebanyak } 77 \text { orang ( } 67 \%) \\
\text { - } 25-34 \text { tahun sebanyak } 11 \text { orang }(9.6 \%) \\
\text { - } 35-49 \text { tahun sebanyak } 12 \text { orang }(10.4 \%) \\
\text { - } 50-64 \text { tahun sebanyak } 15 \text { orang }(13 \%)\end{array}$ \\
\hline $\begin{array}{l}\text { Pendidikan } \\
\text { terakhir }\end{array}$ & $\begin{array}{l}\text { - SMA/sederajat sebanyak } 66 \text { orang ( } 57.4 \%) \\
\text { - } \text { Diploma sebanyak } 11 \text { orang }(9.6 \%) \\
\text { - S-1 sebanyak } 29 \text { orang }(25.2 \%) \\
\text { - } \text { S-2 sebanyak } 9 \text { orang }(7.8 \%) \\
\end{array}$ \\
\hline Pekerjaan & $\begin{array}{l}\text { - Pelajar/mahasiswa sebanyak } 71 \text { orang } \\
(61.7 \%) \\
\text { - Pegawai Negeri sebanyak } 13 \text { orang }(11.3 \%) \\
\text { - Pegawai Swasta sebanyak } 14 \text { orang }(12.2 \%) \\
\text { - Pedagang sebanyak } 2 \text { orang }(1.7 \%) \\
\text { - Polri sebanyak } 1 \text { orang }(0.9 \%) \\
\text { - Marketing freelance } 1 \text { orang }(0.9 \%)\end{array}$ \\
\hline
\end{tabular}

- Ibu rumah tangga 3 orang (2.6\%)

- Pensiunan 5 orang (4.5\%)

- Guru 1 orang $(0.9 \%)$

\section{Analisis Data}

Dari data yang penulis dapatkan melalui kuesioner, dapat dianalisis mengenai kecenderungan pasien terhadap lingkungannya.

Kuesioner Bagian I : Untuk mengetahui pernyataan pasien mengenai fasilitas dan pengalaman psikologis terkait dengan persepsi pasien terhadap rumah sakit. Pertanyaan berkaitan dengan fasilitas rumah sakit apakah memberikan kenyamaan saat pasien menjalani perawatan di rumah sakit. Data yang dapat disimpulkan sesuai dengan Gambar 2.

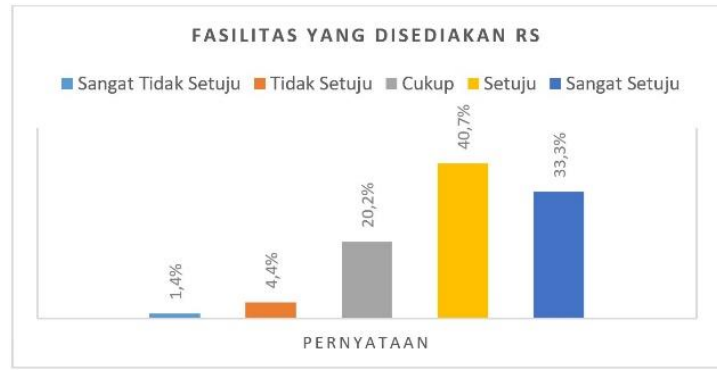

Gambar 2. Fasilitas RS terhadap kenyamanan pasien (Sumber : Analisis Penulis, 2019)

Berdasarkan hasil kuisioner, sebagian besar pasien merasakan kenyamanan ketika dirawat di rumah sakit dengan kondisi; bersih, nyaman, pelayan kesehatan yang ramah, dan dengan suasana rumah sakit yang tenang.

Pertanyaan berikutnya berkaitan dengan persepsi pasien tentang pengalamannya dirawat di rumah sakit, didapatkan data seperti pada Gambar 3.

PERSEPSI NEGATIF PASIEN

m Sangat Tidak Benar $\mathbf{m}$ Tidak Benar $\mathbf{m}$ Cukup $\mathbf{m}$ Benar $\mathbf{m}$ Sangat Benar

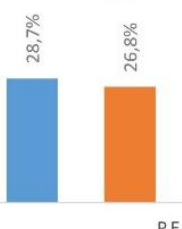

$$
\text { PERNYATAAN }
$$

Gambar 3. Grafik persepsi Pasien terhadap RS

( Sumber : Analisis Penulis, 2019)

a. Sebagaian besar pasien menyatakan bahwa rasa optimis untuk sembuh lebih besar, dibandingkan dengan rasa pesimis.

b. Sebagian besar pasien dapat mengatasi kecemasan dan tekanan ketika dirawat dirumah sakit dengan bantuan dan dukungan keluarga dan orang-orang terdekat.

c. Melalui sugesti positif tersebut dapat mempercepat proses kesembuhan. Namun 
terlepas dari optimisme tersebut, masih ada beberapa pasien yang merasa takut, tertekan dan mempunyai rasa cemas yang berlebih saat dirawat di rumah sakit. Hal ini tentunya harus menjadi bahan pertimbangan untuk penyediaan rumah sakit.

Kuesioner Bagian II : kuesioner bagian II dimaksudkan untuk mengetahui tanggapan pasien terkait dengan penerapan konsep lingkungan alam pada rumah sakit. Data yang dapat disimpulkan penulis sebagai berikut sesuai dengan Gambar 4.

KONSEP LINGKUNGAN ALAM PADA RUMAH SAKIT

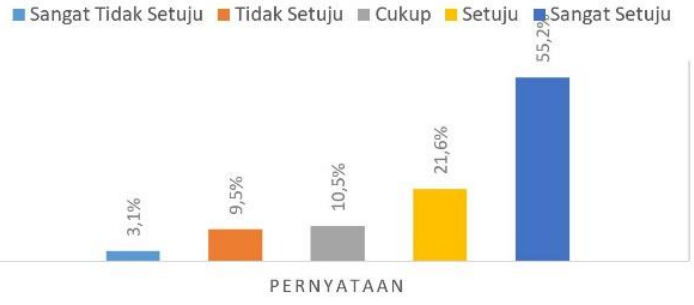

Gambar 4. Persepsi Pasien terhadap penerapan konsep alam (Sumber: Analisis Penulis, 2019)

a. Sebagian besar pasien menginginkan desain rumah sakit yang mengaplikasikan konsep lingkungan alam, seperti adanya taman-taman di dalam ataupun di luar rumah sakit, baik untuk kepentingan visual, terapi penyembuhan, ataupun area bermain.

b. Sebagaian besar pasien juga menginginkan desain rumah sakit yang menyediakan elemen air seperti kolam ikan dengan bebatuan alam dan material kayu di dalamnya.

Kuesioner Bagian III : Kuesioner bagian III dimaksudkan untuk mengetahui perasaan nyaman pasien ketika berada di suasana alam dan di luar suasana alam. Data yang dapat disimpulkan penulis adalah sebagai berikut sesuai dengan Gambar 5 dan Gambar 6.

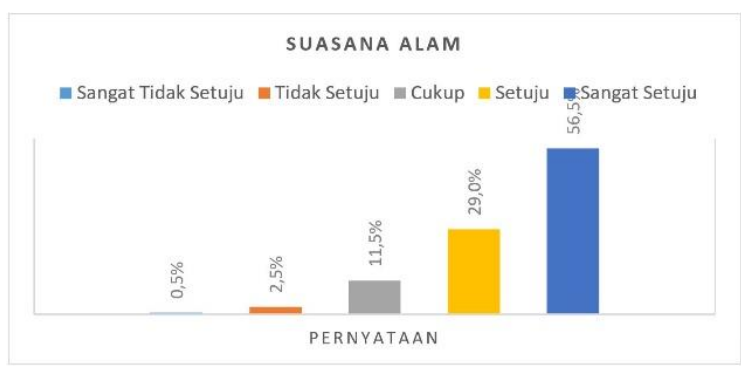

Gambar 5. Persepsi Pasien terhadap kenyamanan di RS (Sumber : Analisis Penulis, 2019)

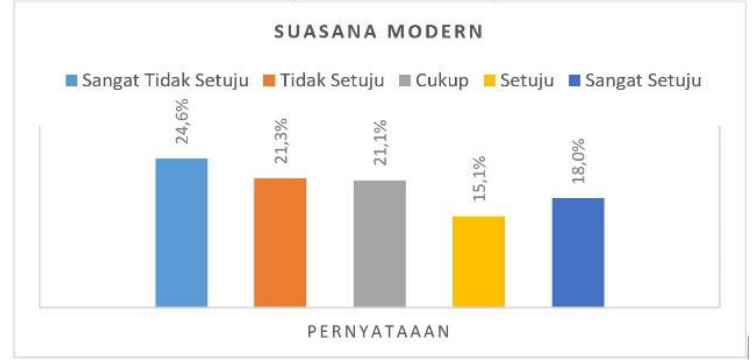

Gambar 6. Persepsi Pasien terhadap suasana RS (Sumber : Analisis Penulis, 2019)

Sebagian besar pasien memberikan penilaian bahwa suasana lingkungan alam dan penambahan elemen tumbuhan pada bangunan lebih dapat memberikan kenyamanan, daripada ruangan dengan konsep modern. Selain kenyamanan, elemen tumbuhan juga dapat memperindah visual dan menambah kesejukan termal.

Kuesioner Bagian IV : Kuesioner bagian IV dimaksudkan untuk mengetahui keinginan dan kecenderungan pasien terhadap dua rumah sakit yang memiliki konsep yang berseberangan, dan pasien diharuskan memilih salah satu dari rumah sakit tersebut. Data yang dapat disimpulkan adalah sesuai dengan Gambar 7.

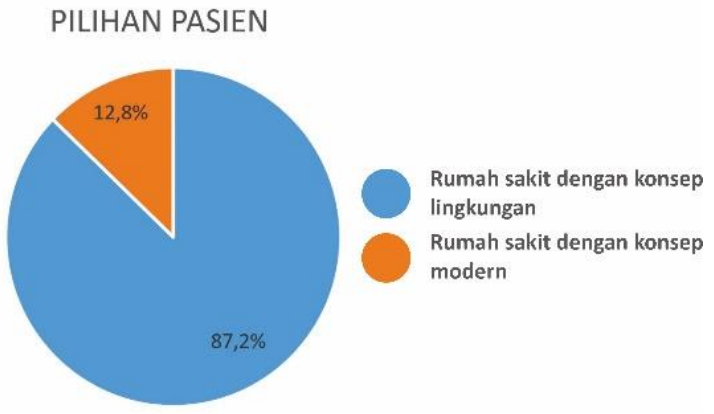

Gambar 7. Persepsi Pasien terhadap konsep lingkungan RS (Sumber : Analisis Penulis, 2019)

Sebanyak $87.2 \%$ dari responden lebih memilih rumah sakit dengan konsep lingkungan alam dan elemen-elemen alam. Artinya lebih dari separuh responden memiliki kecenderungan di alam yang sama.

Analisis data memperoleh kesimpulan bahwa manusia memiliki kecenderungan memiliki keterikatan dengan alam. Dalam hal desain, dengan penempatan di luar atau di dalam bangunan, dengan situasi dan pengaplikasian yang berbeda pun manusia lebih condong kepada segala sesuatu yang berhubungan dengan lingkungan alam. 


\section{PEMBAHASAN}

\section{Hubungan Manusia dengan Lingkungan}

Berdasarkan data dan analisis membuktikan kesesuaian teori biophilia tentang kecenderungan manusia untuk berafiliasi dengan lingkungan (Zakiyaturrahmah, 2017). Kedekatan manusia dengan lingkungan menimbulkan hubungan timbal balik yang saling menguntungkan. Manusia membutuhkan alam untuk tempat tinggal, hidup dan berkembang. Alam membutuhkan manusia untuk merawat kelestariannya. Kesadaran terhadap peran besar lingkungan ini menyadarkan manusia untuk selalu dekat dengan lingkungan sebagai aspek kehidupan.

Penelitian ini menghasilkan data bahwa di dalam sebuah desain bangunan pun, manusia lebih merasa nyaman ketika faktor lingkungan dihadirkan di dalam desain interior tersebut. Artinya keterikatan manusia dengan lingkungan membuat hubungan ini tidak dapat dilepaskan.

\section{Faktor yang Mempengaruhi Kesehatan dan Kesembuhan Manusia}

Menurut psikologi kesehatan dan pengobatan behavioral cara berpikir dapat mempengaruhi kondisi tubuh. Psikologi kesehatan merupakan salah satu subdisiplin pengobatan behavioral yang secara spesifik berhubungan dengan proses-proses psikologis, misalnya kognisi, suasana perasaan, dan jaringan sosial, yang dapat mempengaruhi kesehatan dan penyakit (Pomerantz, 2014).

Cara berpikir dapat memberikan sugesti terhadap kondisi tubuh. Dalam hal kesehatan, selain pola hidup, pengendalian cara berpikir sangat dibutuhkan untuk mencapai tingkat kesehatan tubuh. Tetap menjaga pola hidup sehat dan tidak membebani diri dengan pikiran berat, mensugesti diri dengan hal positif, dapat meningkatkan sistem imun tubuh. Hal ini mengakibatkan terjaganya sistem kekebalan tubuh dan mencegah antigen untuk masuk ke dalam tubuh, sehingga mengecilkan peluang terhadap resiko terkena penyakit.

Beban pikiran berat, kecemasan, rasa takut, dan tanpa adanya sugesti positif dapat meningkatkan resiko depresi dan stres. Stres dapat berdampak buruk bagi kesehatan. Dalam banyak literatur yang dijelaskan, stres telah sering dikaitkan dengan banyak gejala dan penyakit, mulai dari penyakit ringan sampai berat. Di dalam buku Psikologi Klinis, yang ditulis oleh Andrew M. Pomerantz (2014) menjelaskan, respon tubuh terhadap stres dapat mengakibatkan masalah kesehatan seperti :

1. Meningkatnya kadar hormon tiroid yang menyebabkan insomnia dan penurunan berat badan.
2. Menipisnya endorfin, yang menyebabkan sakit jasmaniah.

3. Berkurangnya hormon seks yang berakibat pada amenore dan kesuburan.

4. Mati atau beristirahatnya sistem pencernaan, yang menyebabkan pusing, kembung, mulut kering dan masalah lain.

5. Pelepasan kolesterol yang berlebih yang dapat menyebabkan penyumbatan pada arteri, meningkatkan tekanan darah sampai dengan $400 \%$, stroke, atau aneurisma.

Tingkat yang paling membahayakan dari stres adalah menurunya sistem imun tubuh. Stres mengaktifkan Hipotalamus pituitari-adrenal (HPA) aksis yang mengontrol pelepasan hormon stres yaitu kortisol. Stres kronis dapat meningkatkan kadar kortisol, yang mengakibatkan kemunduran pada sel-T, sel yang sangat esensial di dalam sistem kekebalan tubuh. Sel-T menyerang patogen asing dan sekaligus meregulasi sel-sel lain di dalam sistem kekebalan tubuh. Ketika kadar kortisol yang teregulasi menyebabkan menurunya fungsi sel-T, hasilnya adalah melemahnya sistem kekebalan. Atau lebih mudahnya, stres kronis dapat menyebabkan seseorang menjadi sakit (Pomerantz, A.M., 2014, p. 553).

Faktor yang menentukan seberapa baik seseorang menangani stres ada dua, secara natur (genetik) dan nurtur (non-genetik). Para ahli psikolog mengatakan genetik adalah faktor yang melekat dan pengendaliannya masing-masing individu berbeda, sehingga psikolog tidak dapat berbuat banyak terkait dengan penanganan stres melalui faktor ini. Tetapi melalui faktor nurtur (non-genetik) untuk penanganan stres harus ada peran psikologis individu itu sendiri, salah satunya adalah faktor persepsi untuk menentang kesalahpahaman kognitif dan menggantinya dengan sudut pandang yang lebih sehat.

Sebagaimana yang telah dijelaskan, faktor yang dapat mempengaruhi kesembuhan secara umum dapat diklasifikasikan menjadi 4, diantaranya ; faktor medis (melalui pengobatan medis), faktor genetik bawaan, faktor psikologis, dan faktor lingkungan. Dua diantara empat faktor tersebut dapat dikendalikan melalui hubungan antara pikiran dengan perilaku, yaitu faktor psikologis dan faktor lingkungan.

\section{Pengaruh Konsep Healing Environment pada Rumah Sakit terhadap Kesembuhan.}

Konsep Healing Environment merupakan bentuk pengembangan dan pengaplikasian konsep sebagai respon atas terbuktinya riset yang menunjukan bahwa faktor lingkungan berpengaruh besar terhadap faktor penentu kualitas penyembuhan pasien. Konsep ini memiliki tiga aspek pendekatan, yaitu pendekatan alam, rangsangan indera, dan psikologis. Pendekatan 
alam dipilih karena alam memiliki sifat restoratif terhadap manusia, yang mampu menurunkan tingkat stres, menstabilkan atau menurunkan tekanan darah, dan meningkatkan energi.

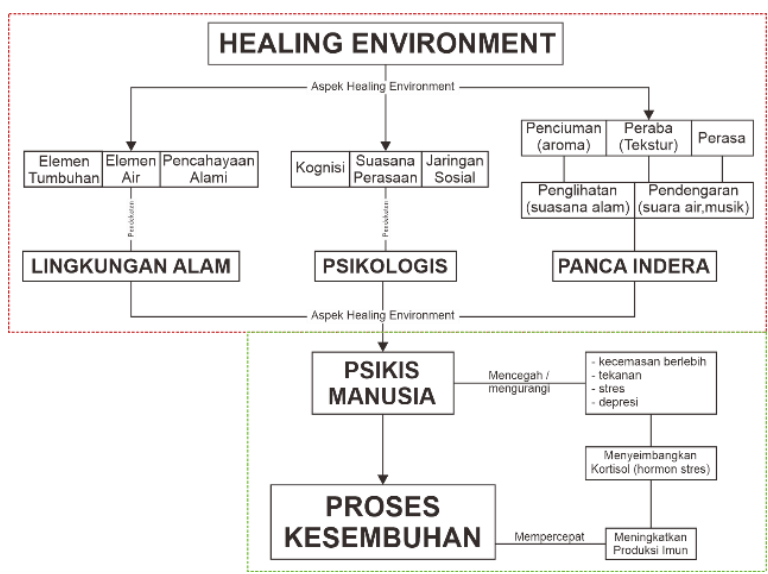

Gambar 8. Bagan Pengaruh Healing Environment terhadap Kesembuhan (Sumber: Analisis penulis, 2019)

Desain rumah sakit yang hadir dengan membentuk suasana alam, melalui tumbuhan, elemen-elemen air, material kayu dan sedikit bebatuan dengan tatanan tertentu, dapat mempengaruhi pikiran pasien untuk lebih merasa rileks dan nyaman dengan suasana rumah sakit. Dalam ilmu kesehatan suasana perasaan dan kognisi yang baik dapat mencegah dan mengatur peningkatan kortisol (hormon stres). Sehingga kortisol dapat bekerja secara optimal dan berimbang, hal ini berakibat terhadap peningkatan sistem kekebalan tubuh pasien yang dapat mempercepat kesembuhan dan pencegahan terhadap penyakit.

Lingkungan alamiah maupun lingkungan buatan memiliki pengaruh dalam menciptakan suatu kesatuan lingkungan yang kondusif bagi proses penyembuhan, tidak hanya kondisi fisik tetapi juga psikis. Kondisi psikis yang prima secara langsung maupun tidak langsung akan memberi stimulus positif terhadap kondisi fisik seseorang sehingga mempercepat berlangsungnya proses penyembuhan.

Pendekatan kedua melalui aspek rangsangan indera yang meliputi pendengaran, pengelihatan, penciuman, perasa dan peraba. Melalui indera manusia, Konsep Healing Environment pada rumah sakit berfokus untuk membangun kesan melalui; visual suasana, suara, aroma, dan tekstur. Konsep lingkungan alam haruslah mendapat porsi besar di dalam desain sebuah rumah sakit, sebab melalui konsep tersebut terapi rangsangan indera dapat dihadirkan, sebagaimana Tabel 2.
Tabel 2. Pengaplikasian Elemen Alam sebagai Rasangan Indera Manusia

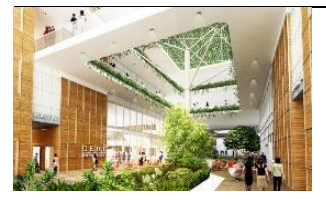

Penambahan elemen-elemen tumbuhan pada ruang dalam rumah sakit sebagai rangsangan indra penglihatan manusia untuk menghasilkan keindahan visual.

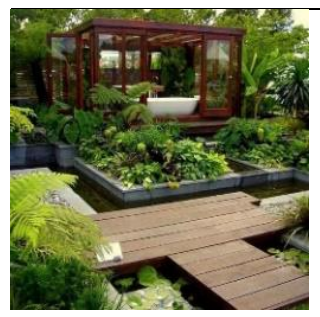

Elemen air pada desain rumah sakit. Melalui kolam ikan dengan gemercik suara air bisa menjadi pilihan untuk merangsang indera pendengaran untuk relaksasi pasien melalui suara.

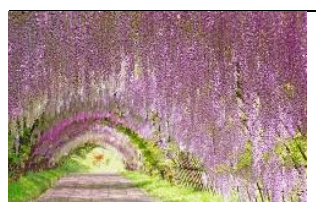

Menanam bunga-bunga beraroma wangi di dalam atau di luar ruangan untuk memberi aroma relaksasi.

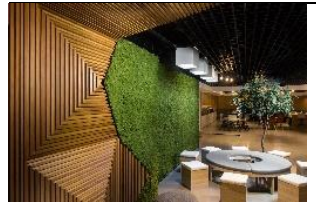

Mengaplikasikan material alam dan material kayu yang bertekstur di sebagian ruang rumah sakit, sebagai respon terhadap indera peraba.

Pendekatan ketiga melalui aspek psikologis. Dengan memberikan stimulus positif terhadap kondisi jiwa, bisa melalui lingkungan sosialnya, keluarganya, dan kehidupan relegiusnya untuk membentuk hubungan positif antara pikiran dan perilaku pasien. Rumah sakit menyediakan fasilitas berupa ruang untuk berkumpul, ruang komunal, taman penyembuhan, dan lain sejenisnya untuk tempat bersosialisasi, komunikasi antar sesama dan keluarga untuk membentuk stimulus mengenai rasa optimisme terhadap sehat, menumbuhkan kepercayaan, meningkatkan semangat sembuh untuk menekan stres pasien saat menjalani perawatan.

Konsep Healing Environment di dalamnya memuat aspek-aspek penting mengenai lingkungan dan psikologis manusia terhadap proses kesembuhan. Apabila saling dikaitkan antara lingkungan, psikologis, kesehatan dan kesembuhan, keempat hal tersebut mempunyai hubungan yang saling berpengaruh satu sama lain. Melalui lingkungan manusia mempunyai kedekatan yang mempengaruhi rasa (kenyamanan, relaksasi, optimisme dan ketentraman).

Kondisi jiwa yang demikian akan menekan tingkat stres dan depresi pasien pada keadaan ataupun suasana di dalam rumah sakit. Stres dan depresi dapat meningkatkan kortisol (hormon stres), dengan peningkatan tersebut akan menurunkan sistem imun tubuh, sehingga dengan turunnya sistem 
imun akan memperlambat kesembuhan dan yang paling merugikan dapat membuat antigen masuk kedalam tubuh dan membuat penyakit baru.

Oleh karena itu, rumah sakit harus memiliki fasilitas penyembuh yang lengkap, baik secara medis maupun secara non medis. Dengan menerapkan konsep Healing Environment rumah sakit akan dapat memaksimalkan perannya terhadap suatu proses kesembuhan.

\section{KESIMPULAN}

Kebenaran teori biophilia mengenai kecenderungan manusia berafiliasi dengan alam memang terbukti, baik yang diaplikasikan di luar ataupun di dalam ruang, baik sebagai pasien ataupun bukan pasien. Lebih dari 80\% atau kurang lebih 92 orang dari 115 orang, memilih suasana yang menghubungkan dengan lingkungan alam. Hal ini membuktikan bahwa dengan keberadaan elemen tumbuhan, elemen air, dan pencahayaan alami di suatu ruang dapat membuat manusia merasakan kenyamanan lebih terhadap suasana ruang.

Hubungan antara pikiran dan perilaku menentukan tata laku seseorang, terlebih bagi seorang pasien. Kognisi, suasana pikiran dan jaringan sosial yang positif sangat dibutuhkan untuk mengatur perilakunya menuju kesembuhan. Melalui pembentukan kognisi, suasana pikiran dan jaringan sosial yang positif memberikan perbaikan besar terhadap kondisi psikologis pasien. Hal ini bertujuan untuk penyembuhan psikis pasien agar tertanam optimisme dan harapan sehat.

Healing Environment adalah konsep yang di dalamnya memuat dua aspek penting mengenai lingkungan alam dan psikologis manusia. Penelitian ini telah membuktikan bahwa pentingnya rumah sakit menerapkan konsep Healing Environment untuk menunjang proses kesembuhan pasien, selain faktor medis yang penting juga untuk dipenuhi.

\section{DAFTAR PUSTAKA}

Afra, Mustika \& Nuffida, Nur, Endah. 2017. “Aspek Alam sebagai Bagian Therapeutic Architecture pada Rumah Sakit Ketergantungan Obat". Jurnal Sains dan Seni ITS Vol. 6 No. 1. Surabaya.

Kurniawati, F. 2007. "Peran Healing Environment terhadap Proses Kesembuhan". Mahasiswa Jurusan Teknik Arsitektur. Yogyakarta.

Pomerantz, A.M., 2014, Psikologi Klinis. Edisi 3. Yogyakarta: Pustaka Pelajar

Susanto, Pauline dkk. 2016. Penerapan Pendekatan Healing Environment pada Rumah Perawatan Paliatif bagi Penderita Kanker, JURNAL INTRA Vol. 4, No. 2 (hlm. 352-360).
Zakiyaturrahmah, A.H., R. Nugroho, L. Pramesti, 2017, Penerapan teori biophilic design dalam strategi perancangan sekolah alam sebagai sarana pendidikan dasar di Karanganyar, Jurnal Arsitektura, Vol. 15, Surakarta: Universitas Sebelas Maret 